\title{
Good Corporate Governance Memoderasi Pengaruh Financial Distress Terhadap Manajemen Laba
}

\author{
Agung Ridangga Puri ${ }^{1}$ \\ Gayatri $^{2}$ \\ ${ }^{1}$ Fakultas Ekonomi dan Bisnis Universitas Udayana (Unud), Bali - Indonesia \\ email: agungpuri71@yahoo.com/ Telp: +6282145673008 \\ ${ }^{2}$ Fakultas Ekonomi dan Bisnis Universitas Udayana (Unud), Bali - Indonesia
}

\begin{abstract}
ABSTRAK
Informasi laba merupakan komponen dari laporan keuangan yang dapat menjadi sasaran rekayasa manajemen untuk memaksimumkan kepentingan pribadinya. Perbaikan pengelolaan di dalam perusahaan diperlukan untuk menekan tindak kecurangan yang dilakukan oleh manajemen tersebut, salah satunya dengan menerapkan konsep Good Corporate Governance (GCG) dalam perusahaan. Tujuan dari penelitian untuk mendapatkan bukti secara empiris mengenai pengaruh financial distresspada manajemen laba dengan Good Corporate Governance (GCG) sebagai variabel pemoderasi. Penelitian dilakukan pada perusahaan LQ45 yang terdaftar di BEI tahun 2012-2016. Teknik Analisis data yang digunakan yaitu uji Moderated Regression Analysis. Hasil penelitian, diketahui bahwa financial distress berpengaruh pada manajemen laba. Penelitian juga menemukan bahwa GCG mampu memperlemah pengaruh financial distressterhadap manajemen laba.
\end{abstract}

Kata Kunci: manajemen laba, financial distress, good corporate governance

\begin{abstract}
The profit information that is part of the financial statements is often the target of management to maximize its personal interests. Improvement of corporate management is needed to suppress the fraud committed by the management, one of which is applying the concept of Good Corporate Governance (GCG) within the company. This study aims to obtain empirical evidence about the influence of lfinancial distress on earnings management with Good Corporate Governance (GCG) as a moderator. This research was conducted at the $L Q 45$ company from 2012-2016 and listed on the Indonesia Stock Exchange.The method which is used in this research is Moderated Regression Analysis. The result of research, it is known that financial distress has effect on earnings management. The study also found that GCG is able to moderate the effect of leverage on earnings management.

Keywords: earnings management, financial distess, good corporate governance
\end{abstract}

\section{PENDAHULUAN}

Dasar akrual dipilih dalam penyusunan laporan keuangan karena lebih rasional dan adil dalam mencerminkan kondisi keuangan perusahaan secara riil. Namun penggunaan dasar akrual ini memungkinkan untuk dapat memodifikasi laporan keuangan untuk menghasilkan jumlah laba (earnings) yang diinginkan. Metode 
akuntansi yang dipilih secara sengaja oleh manajemen untuk tujuan tertentu dikenal dengan manajemen laba (earnings management). Manajemen laba merupakan tindakan manajemen dalam proses menyusun laporan keuangan sehingga dapat menaikan atau menurunkan laba akuntansi sesuai kepentingan. Dalam proses penyajian laporan keuangan, sering terjadi asimetri informasi antara manajemen dan pemegang saham. Manajemen dapat memanfaatkan fleksibilitas dan informasi yang dimiliki untuk tujuan tertentu yang bersifat opportunistik, misalnya untuk memperoleh bonus dan kompensasi lainnya, memengaruhi keputusan pasar modal, menghindari pelanggaran perjanjian utang, dan biaya politik (Perwitasari, 2014).

Terdapat indikasi mengenai manajemen laba seperti yang dilakukan oleh PT Kimia Farma Tbk. PT Kimia Farma didugamelakukan manipulasi laba pada tahun 2011.Kimia Farma mempublikasi laba sebesar Rp 132 miliar. Selain kasus PT. Kimia Farma Tbk, PT. Katarina Utama Tbk diduga telah melalukakn mark up pada laporan keuangan seperti yang dilaporkan oleh salah satu pemegang sahammnya yakni PT. Media Intertel Graha (MIG). Laporan keuangan 2009 yang mencantumkan pendapatan dari MIG Rp 6.773 miliar dan adanya piutang usaha dari MIG sebesar Rp 8.606 miliar.

Salah satu faktor munculnya praktik manajemen laba adalah kondisi kesulitan keuangan (financial distress). Kesulitan keuangan (financial distress) adalah suatu kondisi perusahaan sedang mengalami penyimpangan dan tekanan keuangan yang secara betahap akan mengarah kepada kebangkrutan (Ware, 2015). Perusahaan yang mengalami kondisi kesulitan keuangan cenderung melakukan 
praktik manajemen laba untuk selalu memberikan signal baik di mata investor. Perilaku manajemen laba meningkat seiring meningkatnya kondisi kesulitan keuangan yang dialami perusahaan. Peneliti terdahulu mengatakan bahwa financial distress mempengaruhi pihak manajemen untuk melakukan praktik manajemen laba. Tata kelola perusahaan yang buruk juga dapat mendorong terjadinya manajemen laba.

Terdapat beberapa penelitian mengenai financial distressyang dilakukan oleh salah satunyaSaraswati, dkk. (2014) financial distress memiliki pengaruh positif terhadap manajemen laba. Berdasarkan hasil penelitian yang di lakukan Hapsoro dan Hartono (2016) financial distres berpengaruh positif terhadap manajemen laba. Perusahaan yang mengalami financial distress akan segera mengambil tindakan untuk merespon kondisi tersebut. Kondisi net inome negatif cenderung melakukan manajemen laba untuk menurunkan laba (incomedecreasing) dengan cara mengakui semua beban pada saat ini hingga di tahun depan seolah-olah ada peningkatan laba (perbaikan kondisi) pada perusahaan tersebut. Sehingga, para investor akan melihat jika perusahaan tersebut sudah bangkit atau semakin distress semakin melakukan manajemen laba (Francisca, dkk. 2014).

Beberapa kasus manajemen laba yang masih terjadi menggambarkan bahwa manajer masih mempunyai kesempata untuk memanipulasi laporan keuangan. Hal tersebut menimbulkan pertanyaan apakah implementasi GCG sudah efektif atau belum penerapannya dalam meminimalisir manajer melakukan manajemen laba. Kemungkinan perilaku oportunistik ini meningkat dengan 
adanya penerapan GCG yang lemah, yang akhirnya menyebabkan kualitas laba yang dilaporkan tidak sesuai dan mengurangi kepercayaan investor terhadap laporan keuangan (Gonzalez \& Garcia-Meca, 2014).

Masih adanya ketidakkonsistenan hasil penelitian terdahulu mengenai financial distress, dan adanya variabel lain yakni kualitas good coporate governance yang terindikasi dapat memperkuat maupun memperlemah praktik manajemen laba, maka mendorong peneliti melakukan penelitian kembali untuk melihat pengaruh financial distress tersebut pada praktik manajemen laba dan apakah dengan Good Corporate Governance dapat meminimalkan tindakan manajemen laba yang ada di dalam perusahaan. Rumusan masalah yang dapat diajukan yaitu apakah financial distressberpengaruh terhadap manajemen laba? Serta apakah good corporate governance mampu memperlemah pengaruh financial distresspada manajemen laba?.

Tujuan penelitian iniuntuk memeroleh bukti secara empiris mengenai pengaruh financial distresspada manajemen laba dan GCG mampu memperlemah pengaruh financial distresspada manajemen laba. Harapannya penelitian ini mampu memberikan dapat menambah referensi, informasi, dan wawasan serta memberikan pemahaman yang lebih luas berkaitan dengan pengaruh financial distress terhadap manajemen laba dan GCG mampu memperlemah pengaruh financial distress terhadap manajemen laba pada perusahaan LQ45 yang terdaftar di BEI.

Hasil penelitian ini juga diharapkan dapat memberikan informasi penting bagi pihak perusahaan yaitu dengan penelitian ini diharapkan dapat memberikan 
pertimbangan mengenai penerapan good corporate governance di dalam perusahaan. Bagi investor, penelitian ini diharapkan dapat membantu atau untuk dapat dijadikan pertimbangan dalam menentukan keputusan berinvestasi. Hubungan antara pihak yang memberi wewenang dengan pihak yang menerima wewenang disebut dengan kontrak kerja (Triwahyuningtias 2012).Hubungan keagenan dapat dikatakan baik apabila agen dapat menjalankan wewenang dari prinsipal dan dapat mempertanggungjawabkan kinerjanya kepada prinsipal(Firdausya, dkk 2013).Perbedaan kepentingan oleh agent dan principal, menyebabkan munculnya keinginan oleh pihak manajemen untuk melakukan praktik manajemen laba (Peranasari dan Dharmadiaksa, 2014). Teori keagenan dilandasi 3 asumsi dasar, yaitu asumsi sifat dasar manusia, asumsi keorganisasian, dan asumsi informasi.

Signalling theory dapat menjelaskan alasan perusahaan mempunyai dorongan untuk memberikan informasi laporan keuangan pada pihak eksternal. Dorongan perusahaan untuk memberikan informasi karena terdapat asimetri informasi antara perusahaan dan pihak luar karena perusahaan mengetahui lebih banyak mengenai perusahaan dan prospek yang akan datang dari pihak luar (Karasek and Bryant, 2012).

Manipulasi laba atau manajemen laba merupakan pemanfaatan celah dalam penggunaan dasar akrual oleh pihak manajemen disaat penyusunan laporan keuangan sehingga manajer dapat mengatur laba dengan menaikan, menurunkan, atau meratakan laba dikenal dengan istilah manajemen laba (Mahariana dan Ramantha, 2014). Dalam kondisi perusahaan akan menjual sahamnya kepada publik, 
manajer perlu memberika informasi kepada publik mengenai kondisi keuangan perushaannya. Hal ini mendorong manajer untuk melakukan eranings management (Hidayat, 2016). Manipulasi laba dilakukan dengan cara menaikan atau menurunkan laba sesuai dengan kemauan pihak manajer, sehingga memberikan gambaran yang bias bagi pemakai laporan keuangan dalam mempercayai angka-angka pada laporan keuangan.

Kausalty et al. (2013) menyatakan bahwaGood Corporate Governance (GCG) adalah suatu konsep yang diimplementasikan untuk meningkatkan kinerja perusahaan yangmengacu pada sistem, prinsip-prinsip dan proses di mana sebuah perusahaan diatur.Bistrova dan Lace (2012), menemukan bahwa perusahaan yang memiliki tata kelola yang baik akan meminimalisi adanya manipulasi laporan keuangan. Mekanisme Good Corporate Governance (GCG) dapat dilihat dari kepemilikan institusional, kepemilikan manajerial, dewan komisarin independen, dan komite audit. GCG ini diterapkan demi terwujudnya pengelolaan perusahaan yang transparan untuk semua pemakai laporan keuangan (Hapsoro dan Hartono, 2016).

Kepemilikan manajerial adalah kepemilikan saham oleh manajemen perusahaan yang diukur dengan persentase saham yang dimiliki oleh manajemen. Kepemilikan manajerial sebagai suatu mekanisme pengawasan yang bertujuan untuk menyelaraskan berbagai kepentingan dalam perusahaan (Hidayat, 2016). Kepemilikan institusional adalah kepemilikan saham oleh pemerintah institusi keuangan pada akhir tahun. Adanya kepemilikan institusional di suatu perusahaan akan mendorong peningkatan pengawasan agar lebih optimal terhadap kinerja manajemen (Hidayat, 2016). Dewan komisaris independen memegang peranan penting dalam implementasi GCG karena merupakan inti dari GCG yang bertugas 
untuk menjamin pelaksanaan strategi perusahaan dan komite audit bertugas untuk membantu dewan komisaris dalam memastikan efektivitas sistem pengendalian internal dan efektivitas pelaksanaan tugas auditor eksternal dan internal (Hidayat, 2016.

Adapun kerangka konseptual dalam penelitian ini menunjukkan pengaruh antar variabel dalam penelitian. Kerangka konseptual dalam penelitian ini disajikan pada gambar 1 sebagai berikut.

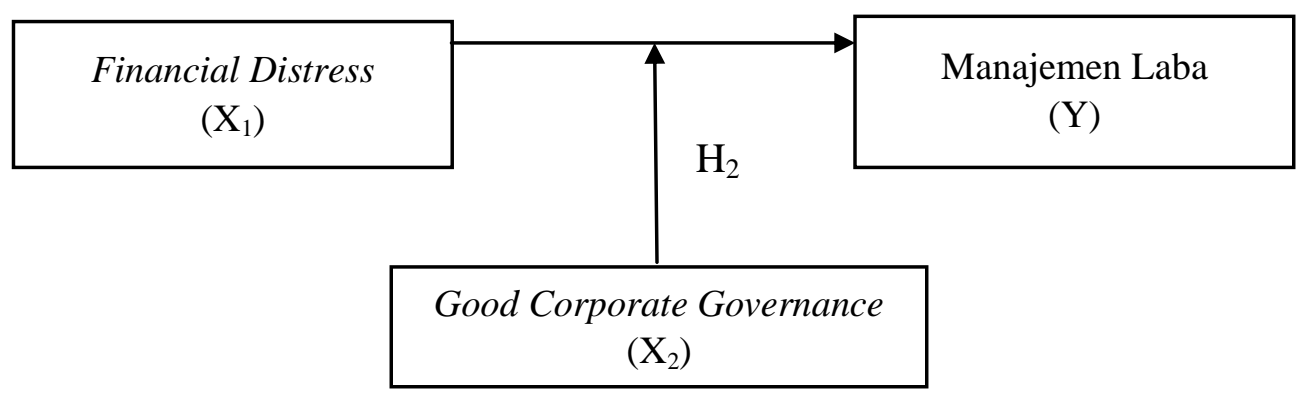

Gambar 1.

\section{Kerangka Konseptual}

Perusahaan yang mengalami financial distress akan segera mengambil tindakan untuk merespon kondisi tersebut. Perusahaan merespon kondisi kesulitan keuangan dengan melakukan manajemen laba.Hasil penelitian yang dilakukan oleh Saraswati, dkk. (2014) financial distress memiliki pengaruh positif terhadap manajemen laba. Berdasarkan hasil penelitian yang di lakukan Hapsoro dan Hartono (2016) financial distres berpengaruh positif terhadap manajemen laba. Perusahaan yang mengalami financial distress akan segera mengambil tindakan untuk merespon kondisi tersebut. Dengan demikian maka hipotesis yang dapat dikembangkan yaitu:

$\mathrm{H}_{1}$ : Financial distress berpengaruh pada manajemen laba. 
Manajemen laba diyakini muncul sebagai konsekuensi langsung dari upaya-upaya manajer atau pembuat laporan keuangan untuk melakukan manajemen informasi akuntansi, khususnya earnings, demi kepentingan pribadi dan atau perusahaan. Untuk meminimalisir perilaku tersebut maka dibutuhkan suatu tata kelola perusahaan yang baik. Francisca, dkk. (2014) menganalisis hubungan antara financial distress dengan manajemen laba dengan menggunakan enam variabel kontrol, yaitu size, financial distress, operating cash flow, audit quality, kepemilikan saham dan growth. Berdasarkan hasil penelitian, hanya variabel size dan financial distress yang memilikihubungan signifikan dengan manajemen laba.

Penelitian Hapsoro dan Hartono (2016) menganalisis pengaruh proporsi komisaris independen terhadap manajemen laba. Penelitian mereka menemukan bahwa proporsi komisaris independen berpenaruh negatif signifikan terhadap manajemen laba. Dengan demikian maka hipotesis yang dapat dikembangkan yaitu:

$\mathrm{H}_{2}$ : Good corporate governance mampu memperlemah pengaruh financial distress terhadap manajemen laba.

\section{METODE PENELITIAN}

Jenis data dalam penelitian ini adalah data kuantitatif dan kualitatif. Kuantitatif meliputi laporan keuangan tahunan perusahaan yang terdaftar di Bursa Efek Indonesia. Metode penelitian kuantitatif memiliki pengertian sebagai sebuah metode penelitian berdasarkan pada kenyataan dan digunakan untuk melakukan penelitian pada populasi atau sampel tertentu. Pendekatan kuantitatif dengan bentuk asosiatif berdasarkan tipe kausalitas adalah jenis penelitian yang 
memberikan penjelasan mengenai pengaruh variabel bebas terhadap variabel terikat (Sugiyono, 2016: 12). Penelitian ini dilakukan pada perusahaan LQ45 di Bursa Efek Indonesia pada periode 2012-2016 dengan mengakses website resmi Bursa Efek Indonesia yaitu www.idx.co.id.Objek penelitian merupakan suatu sifat objek yang ditetapkan oleh peneliti untuk dipelajari dan kemudian memperoleh kesimpulan (Sugiyono, 2013). Objek pada penelitian ini adalahfinancial distress, manajemen laba, dan GCG pada perusahaan LQ45 di Bursa Efek Indonesia periode 2012-2016.

Berdasarkan rumusan masalah serta hipotesis penelitian yang telah dipaparkan, dapat diidentifikasi manajemen laba (Y).Variabel manajemen laba diukur dengan menggunakan variabel proxy discretionary Accrual (Hidayat, 2016), yang diukur dengan menggunakan model Jones modifikasian (Modified Jones Model). Pemilihan model Modified Jones Model karena model ini dianggap memiliki kemampuan terbaik dalam menjelaskan manajemen laba sesuai dengan penelitian yang dilakukan oleh Dechow et al (1995). Persamaan model Jones modifikasian adalah sebagai berikut.

$\mathrm{TAC}_{\mathrm{it}}=\mathrm{N}_{\mathrm{it}}-\mathrm{CFO}_{\mathrm{it}}$

Nilai total accrual (TA) diestimasi dengan persamaan regresi linear berganda yang berbasis ordinary least square (OLS) sebagai berikut:

$$
\mathrm{TAC}_{\mathrm{it}} / \mathrm{A}_{\mathrm{it}-1}=\beta_{1}\left(1 / \mathrm{A}_{\mathrm{it}-1}\right)+\beta_{2}\left(\Delta \mathrm{REV}_{\mathrm{t}} / \mathrm{A}_{\mathrm{it}-1}-\Delta \mathrm{REC}_{\mathrm{t}} / \mathrm{A}_{\mathrm{it}-1}\right)+\beta_{3}\left(\mathrm{PPE}_{\mathrm{t}} / \mathrm{A}_{\mathrm{it}-1}\right)+\mathrm{e} \ldots \ldots
$$

Dengan menggunakan koefisien regresi di atas nilai nondiscretionary accruals (NDA) dapat dihitung dengan rumus:

$$
\mathrm{NDA}_{i t}==\beta_{1}\left(1 / \mathrm{A}_{\mathrm{it}-1}\right)+\beta_{2}\left(\Delta \mathrm{REV}_{\mathrm{t}} / \mathrm{A}_{\mathrm{it}-1}-\Delta \mathrm{REC}_{\mathrm{t}} / \mathrm{A}_{\mathrm{it}-1}\right)+\beta_{3}\left(\mathrm{PPE}_{\mathrm{t}} / \mathrm{A}_{\mathrm{it}-1}\right) .
$$


Selanjutnya discretionary accrual (DA) dapat dihitung sebagai berikut:

$$
\mathrm{DA}_{\mathrm{it}}=\mathrm{TA}_{\mathrm{it}} / \mathrm{A}_{\mathrm{it}-1}-\mathrm{NDA}_{\mathrm{it}}
$$

Keterangan:

$\mathrm{TAC}_{\mathrm{it}}=$ Total accruals perusahaan i pada periode $\mathrm{t}$

$\mathrm{N}_{\mathrm{it}} \quad=$ Laba bersih perusahaan i pada periode $\mathrm{t}$

$\mathrm{CFO}_{\text {it }} \quad=$ Aliran kas dari aktivitas operasi per-usahaan i pada periode $\mathrm{t}$

$\mathrm{A}_{\mathrm{it}-1} \quad=$ Total aset perusahaan $\mathrm{i}$ pada tahun $\mathrm{t}-1$

$\triangle \mathrm{REV}_{\mathrm{t}} \quad=$ Perubahan pendapatan perusahaan $\mathrm{i}$ dari tahun $\mathrm{t}-1$ ke tahun $\mathrm{t}$

$\triangle \mathrm{REC}_{\mathrm{t}} \quad=$ Perubahan piutang perusahaan $\mathrm{i}$ dari tahun $\mathrm{t}-1$ ke tahun $\mathrm{t}$

$\mathrm{PPE}_{\mathrm{t}} \quad=$ Aset tetap perusahaan tahun $\mathrm{t}$

$\mathrm{DA}_{\mathrm{it}} \quad=$ Discretionary Accruals perusahaan i pada periode ke $\mathrm{t}$

NDA $_{i t} \quad=$ Non Discretionary Accruals perusahaan i pada periode ke $\mathrm{t}$

$\beta \quad=$ Koefisien regresi

e $\quad=$ error

Financial distress (X1) sebagai variabel independen diproksikan dengan menggunakan Debt to Equity RatioKeadaan keuangan perusahaan akan aman jika memiliki nilai DER sebesar $100 \%$. Apabila nilai DER perusahaan berada di atas $100 \%$ maka hal tersebut enunjukan indikasi bahwa kondisi suatu perusahaan sedang memburuk.

DER = Total Liabilities $/$ Total Equity

GCG (X2) sebagai variabel moderasi diukur dengan analisis faktor.Analisis faktor adalah analisis yang digunakan untuk mengukur validitaskonstruk dengan tujuan menunjukan seberapa baik hasil yang diperoleh dari penggunaan pengukur sesuai dengan teori-teori yang digunakan (Sugiyono, 2016:307). GCG dapat diukur dengan empat proksi, yaitu: kepemilikan institusional, kepemilikan manajerial, komisaris independen dan komisi audit. Tujuan dari analisis faktor terhadap proksi-proksi dari GCG guna mencari faktor utama untuk mewakili GCG sebagai variabel moderasi. 
Proksi yang terpilih akan digunakan sebagai perwakilan dari variabel GCG saat melakukan Regression Analysis (MRA). Kemampuan untuk menjelaskan variabel GCG ditunjukan oleh angka communalities, semakin besar angka communalities maka semakin besar kemampuan proksi dalam menjelaskan variabel GCG.

Sebelum menggunakan analisis faktor, variabel GCG diukur dengan empat aspek sebagai berikut :

a) Komisaris Independen (IN)

$\mathrm{IN}=\frac{\mathrm{x}}{\mathrm{y}} \times 100 \%$

$\mathrm{x}=$ jumah komisaris independen pada perusahaan pada periode $\mathrm{t}$

$\mathrm{y}=$ total jumlah komisaris pada sebuah perusahaan pada periode $\mathrm{t}$

b) Komite audit (KA) dihitung melalui jumlahkomite audit yang tersedia di dalam perusahaan

$$
\mathrm{KA}=\frac{\text { JumlahKomiteAudit }}{\text { JumlahAnggotaDewanKomisaris }} \times 100 \%
$$

c) Kepemilikan institusional (KI)

$$
\mathrm{KI}=\frac{\text { jumlahsahamyangdimilikiinstitusional }}{\text { Totalsahamberedar }} \times 100 \%
$$

d) Kepemilikan manajerial (KM) dalam penelitian ini dilakukan dengan melakukan perbandingan saham yang dimiliki oleh pihak manajemen dengan total saham yang terdapat dalam perusahaan

$\mathrm{KM}=\frac{\text { jumlahsahamyangdimilikimanajemen }}{\text { Totalsahamberedar }} \times 100 \%$ 
Laporan keuangan yang telah diaudit serta diakses melalui web resmi BEI pada penelitian ini adalah bentuk data kuantitatif dan data sekunder. Penentuan sampel dari populasi penelitian dipilih metode non probability sampling dan purposive sampling dengan menyertakan beberapa kriteria mencakup: 1). Perusahaan yang mempublikasikan laporan keuangan dan dinyatakan dalam rupiah untuk periode 31 desember tahun 2012-2016.. 2). Perusahaan yang mempunyai data lengkap terkait dengan variabel-variabel yang dibutuhkan selama periode penelitian 2012-2016. 3). Perusahaan yang memiliki data mengenai kepemilikan instusional, kepemilikan manajerial, komisaris independen dan komite audit selama periode 2012-2016.

Berdasarkan kriteria tersebut jumlah observasi yang diperoleh untuk penelitian adalah sebanyak 12 perusahaan dengan 60 total obseravasian. Pada penelitian ini mempergunakan metode pengumpulan data observasi nonpartisipan. Dilakukan Uji Statistik Deskriptif, Uji Asumsi Klasik hingga Uji Moderated Regression Analysis (MRA) yang menghasilkan persamaan sebagai berikut.

$$
\mathrm{Y}=\mathrm{a}+\beta_{1} \mathrm{X}_{1}+\beta_{2} \mathrm{X}_{2}+\beta_{3} \mathrm{X}_{1} \mathrm{X}_{2}+\mathrm{e}
$$

Keterangan:

$$
\begin{array}{ll}
\mathrm{Y} & =\text { Manajemen Laba } \\
\mathrm{a} & =\text { Konstanta } \\
\beta & =\text { Koefisien regresi } \\
\mathrm{X}_{1} & =\text { financial distress } \\
\mathrm{X}_{2} & =\mathrm{GCG}
\end{array}
$$

\section{HASIL DAN PEMBAHASAN}

Setelah dilakukan observasi penelitian, maka perusahaan yang dapat dijadikan sampel adalah sebanyak 12 perusahaan dengan total 60 sampel amatan yang ditunjukan dengan proses seleksi sebagai berikut. 
Tabel 1.

Hasil Seleksi Pemilihan Sampel

\begin{tabular}{llc}
\hline No & \multicolumn{1}{c}{ Kriteria } & $\begin{array}{c}\text { Jumlah } \\
\text { Perusahaan }\end{array}$ \\
\hline 1. & $\begin{array}{l}\text { Perusahaan yang terdaftar dalam LQ45 di Bursa Efek Indonesia (BEI) } \\
\text { 2. }\end{array}$ & $\begin{array}{l}\text { Perusahaan yang tidak menyajikan angka-angka dalam laporan } \\
\text { keuangan dengan mata uang rupiah }\end{array}$ \\
3. & $\begin{array}{l}\text { Perusahaan yang tidak menyajikan data kepemilikan institusional, } \\
\text { kepemilikan manajerial, komite audit dan komisaris independen }\end{array}$ \\
4. $\begin{array}{l}\text { Perusahaan yang tidak memiliki data lengkap terkait variabel yang } \\
\text { dibutuhkan }\end{array}$ & $(30)$ \\
& $\begin{array}{l}\text { Jumlah sampel penelitian } \\
\text { Total Sampel dalam lima tahun penelitian }\end{array}$
\end{tabular}

Sumber: Data diolah, 2017

Keempat proksi GCG tersebut selanjutnya difaktorkan untuk mengelompokan proksi ke dalam satu faktor. Komponen yang terbentuk dari kumpulan proksi tersebut dapat digunakan sebagai variabel baru yang mewakili variabel GCG, yang selanjutnya digunakan untuk analisis regresi. Hasil analisis faktor keempat proksi GCG disajikan pada tabel berikut.

Tabel 2.

Hasil Uji Total Variance Explained Variabel GCG

\begin{tabular}{|c|c|c|c|c|c|c|}
\hline \multicolumn{4}{|c|}{ Initial Eigenvalues } & \multicolumn{3}{|c|}{ Extraction Sums of Squared Loadings } \\
\hline Total & & $\begin{array}{c}\% \text { of } \\
\text { Variance }\end{array}$ & $\begin{array}{c}\text { Cumulative } \\
\%\end{array}$ & Total & $\begin{array}{c}\% \text { of } \\
\text { Variance }\end{array}$ & $\begin{array}{c}\text { Cumulative } \\
\%\end{array}$ \\
\hline & 1,361 & 68,066 & 68,066 & \multirow{2}{*}{1,361} & \multirow{2}{*}{68,066} & \multirow{2}{*}{68,066} \\
\hline & 639 & 31,934 & 100,000 & & & \\
\hline
\end{tabular}

Sumber: Data diolah, 2017

Pada Tabel 2 yang meunjukan nilai eigen value lebih besar atau sama dengan satu varians yang bisa dijelaskan sebesar $68,066 \%$. Berdasarkan kriteria yang digunakan yaitu nilai varians harus lebih besar atau sama dengan $60 \%$, hal ini berarti uji totalvairance explained dari proksi komite audit dan komisaris independen sudah sesuai dengan kriteria validitas konstruk. 
Tabel 3.

KMO and Barllet's Test Variabel GCG

\begin{tabular}{llr}
\hline Kaiser-Meyer-Olkin Measure of Sampling Adequacy. &, 500 \\
\hline Bartlett's Test of Sphericity & Approx. Chi-Square & 8,044 \\
& Df & 1 \\
& Sig. &, 005 \\
\hline
\end{tabular}

Sumber: Data diolah, 2017

Berdasarkan Tabel 3 nilai KMO (Kaise-Mayer-Olkin) Measure of Sampling Adequacy (MSA) sebesar 0,500 (setelah kepemilikan manajerial dan kepemilikan institusional dikeluarkan). Dimana nilai $0,500 \leq 0,50$. Barlett's test of sphericity (chi square) dengan signifikansi kurang dari 1 persen. Demikian juga dengan Anti-Image dari variabel indikator, semua nilainya telah melebihi syarat minimum, yaitu diatas atau sama dengan 0,50.

Tabel 4.

Ringkasan Loading Factor dan Communalities

\begin{tabular}{|c|c|c|}
\hline \multicolumn{3}{|c|}{ Good Corporate Governance } \\
\hline Proksi & Loading Factor & Communalities \\
\hline IN & 0,825 & 0,681 \\
\hline KA & 0,825 & 0,681 \\
\hline
\end{tabular}

Sumber: Data diolah, 2017

Berdasarkan Tabel 4 dapat dijelaskan bahwa semua proksi memiliki faktor loading di atas 0,50. Hal ini menunjukan komite audit dan dewan komisaris independen mampu mewakil GCG dalam penelitian ini. Hal ini menunjukan bahwa dewan komisaris independen mempunyai tugas yaitu mensupervisi dan memberi nasehat kepada dewan direksi, dan dewan komisari independen membentuk komisi audit untuk mengaudit operasi dan keadaan perusahaan serta memastikan bahwa perusahaan telah melaksanakan tanggung jawab kepada para stakeholder. 
Statistik deskriptif digunakan untuk mengetahui jumlah sampel, nilai minimum, nilai maksimum, nilai rata-rata, dan standar deviasi dari masing-masing variabel.

Tabel 5.

Statistik Deskripstif Variabel-Variabel Penelitian

\begin{tabular}{lccccc}
\hline & N & Minimum & Maximum & Mean & $\begin{array}{c}\text { Std. } \\
\text { Deviation }\end{array}$ \\
\hline MANAJEMEN & 60 & $-1,540$ & 0,240 & $-0,1137$ & 0,34788 \\
LABA & 60 & 0,120 & 1,930 & 0,8729 & 0,40676 \\
Financial Distress & 60 & $-1,520$ & 1,770 & 0,0000 & 1,00000 \\
FGCG & & & & & \\
\hline FD*FGCG & 60 & $-1,380$ & 3,410 & 0,1926 & 1,16190 \\
Valid N & 60 & & & & \\
\hline
\end{tabular}

Sumber: Data diolah, 2017

Nilai minimum variabel manajemen laba adalah -1,540 yaitu PT Pakuwon Jati Tbk pada tahun 2014, dan nilai maksimumnya adalah 0,240 yang terdapat pada PT Aneka Tambang (Persero) Tbk pada tahun 2014. Mean untuk manajemen laba adalah 0,1137 hal ini berarti rata-rata manajemen laba pada sampel amatan yang digunakan dalam penelitian ini berjumlah 0,1137. Deviasi standar untuk manajemen laba adalah 0,34788 yang memiliki makna dimana terjadi penyimpangan nilai manajemen laba pada nilai rata-ratanya sebesar 0,34788 .

Nilai minimum variabel Financial Distress adalah 0,120 yaitu PT Ciputa Development Tbk pada tahun 2012, dan nilai maksimumnya adalah 1,930 yang terdapat pada PT Summarecon Agung Tbk pada tahun 2013. Mean untuk Financial Distress adalah 0,8729hal ini berarti rata-rata Financial Distress pada sample amatan yang digunakan dalam penelitian ini berjumlah 0,8729 . Deviasi standar untuk Financial Distress adalah 0,40676 yang memiliki makna dimana 
terjadi penyimpangan nilai Financial Distress pada nilai rata-ratanya sebesar 0,40676 .

Nilai minimum variabel FGCG adalah -1,520 yaitu PT United Tractors Tbk pada tahun 2012-2016, dan nilai maksimumnya adalah 1,770 yang terdapat pada PT Sumarecon Agung (Persero) Tbk pada tahun 2012-2016. Mean untuk FGCG adalah 0,0000hal ini berarti rata-rata FGCG pada sample amatan yang digunakan dalam penelitian ini berjumlah 0,0000. Deviasi standar untuk FGCG adalah 1,00000 yang memiliki makna dimana terjadi penyimpangan nilai FGCG pada nilai rata-ratanya sebesar 1,00000. Selanjutnya dilakukan uji asumsi klasik yang meliputi uji normalitas, uji autokorelasi dan uji heteroskedastisitas untuk mengetahui apakah data dalam penelitian yang dilakukan telah lolos dari asumsi klasik. Uji normalitas menggunakan analisis grafik, dimana dikatakan berdistribusi normal apabila data menyebar disekitar garis diagonal dan mengikuti arah garis diagonal dan dalam penelitian ini telah lolos uji normalitas.

Uji yang kedua dilakukan uji autokorelasi untuk mengetahui korelasi antara kesalahan pengganggu pada periode $\mathrm{t}$ dengan periode $\mathrm{t}-1$.Jika terjadi korelasi maka dikatakan ada autokorelasi. Autokorelasi muncul karena observasi yang berurutan sepanjang waktu berkaitan satu sama lain. Model regresi yang baik dirumuskan kriteria $-2<\mathrm{d}<2$ (Santoso,2012:241). Berdasarkan hasil uji autokorelasi nilai dw yang dihasilkan sebesar 0,417 . Nilai dw berada diantara -2 sampa 2, maka dapat dirumuskan kriteria $-2<\mathrm{d}<2$ yaitu $(-2<0,417<2)$. Hal ini menunjukkan data yang digunakan pada penelitian ini bebas dari autokorelasi. 
Uji asumsi klasik yang digunakan selanjutnya adalah uji heteroskedastisitas. Uji heteroskedastisitas dalam penelitian ini menggunakan Scatterplots yang dapat diketahui bahwa titik-titik menyebar secara acak serta tersebar baik di atas maupun di bawahangka 0 dan tidak membentuk pola, maka dapat disimpulkan bahwa data yang digunakan pada penelitian ini tidak terdapat masalah heteroskedastisitas.

Moderated Regression Analysis (MRA) dalam model persamaan regresi linear berganda untuk mengetahui kemampuan GCG dalam memoderasi pengaruh financial distress terhadap manajemen laba. Hasil pengujian disajikan dalam rekapitulasi hasil analisis regresi regresi linear berganda dengan menggunakan uji interaksi pada tabel 6 sebagai berikut:

Tabel 6.

Rekapitulasi Hasil MRA

\begin{tabular}{|c|c|c|c|c|c|c|}
\hline & \multirow[t]{2}{*}{ Model } & \multicolumn{2}{|c|}{$\begin{array}{l}\text { Unstandardized } \\
\text { Coefficients }\end{array}$} & \multirow{2}{*}{$\begin{array}{c}\text { Standardized } \\
\text { Coefficients } \\
\text { Beta }\end{array}$} & \multirow[t]{2}{*}{$\mathbf{t}$} & \multirow[t]{2}{*}{ Sig. } \\
\hline & & B & Std. Error & & & \\
\hline \multirow[t]{8}{*}{1} & (Constant) & 0,238 & 0,125 & & 1,898 & 0,063 \\
\hline & FINANCIAL & $-0,470$ & 0,150 & $-0,550$ & $-3,142$ & 0,003 \\
\hline & DISTRESS & & & & & \\
\hline & FGCG & $-0,178$ & 0,115 & $-0,512$ & $-1,547$ & 0,128 \\
\hline & FD*FGCG & 0,304 & 0,115 & 1,015 & 2,641 & 0,011 \\
\hline & Adjusted $\mathrm{R}^{2}$ & \multicolumn{5}{|c|}{0,136} \\
\hline & $F_{\text {hitung }}$ & \multicolumn{5}{|c|}{4,104} \\
\hline & Sig. F & \multicolumn{5}{|c|}{0,011} \\
\hline
\end{tabular}

Sumber: Data diolah, 2017

Rekapitulasi hasil analisis regresi linear berganda berdasarkan pada hasil analisis koefisien regresi pada Tabel 6 adalah sebagai berikut:

$\mathrm{Y}=0,238-0,470 \mathrm{FD}-0,178 \mathrm{FGCG}-0,304 \mathrm{FD} \cdot \mathrm{FGCG}+\varepsilon$ 
Nilai konstanta 0,238 menunjukan bahwa bila financial distress dan GCG sama dengan nol, maka manajemen laba akan meningkat sebesar 0,238 satuan. Nilai koefisien regresi FD sebesar -0,470 menunjukan bahwa bila financial distress naik satu satuan, maka manajemen laba akan mengalami penurunan sebesar $-0,470$ satuan dengan asumsi variabel lainnya konstan. Nilai koefisien regresi FGCG sebesar -0,178 menunjukan bahwa bila FGCGnaik satu satuan, maka manajemen laba akan mengalami penurunan sebesar $-0,178$ satuan dengan asumsi variabel lainnya konstan.Nilai koefisien regresi FD.FGCG sebesar 0,304 menunjukan bahwa bila interaksi antara financial distressdengan FGCG naik satu satuan, maka manajemen laba akan mengalami peningkatan sebesar 0,304 satuan dengan asumsi variabel lainnya konstan.

Berdasarkan hasil uji kesesuaian model pada Tabel 6 di atas, dapat dilihat bahwa nilai dari uji F sebesar 7,003 dan nilai p-value (Sig. F) yakni0,001 lebih kecil dari nilai $\alpha=0,05$. Hal ini menunjukkan bahwa model persamaan dalam penelitian ini layak untuk digunakan.

Adapun nilai dari adjustedR square pada penelitian ini telah disajikan pada Tabel 6. Berdasarkan pada Tabel 6 diatas,dapat dilihat bahwa nilai dari uji $\mathrm{F}$ sebesar 4,104 dan nilai $p$-value (Sig. F) yakni0,011 lebih kecil dari nilai $\alpha=0,05$. Hal ini menunjukkan bahwa model persamaan dalam penelitian ini layak untuk digunakan.

Uji hipotesis pertama dengan nilai $\mathrm{t}$ hitung sebesar -3,798dan nilai signifikansi uji t yakni nilai p-value sebesar 0,003 lebih kecil dari $\alpha=0,05$ serta nilai koefisien regresi sebesar -0,470. Ini berarti bahwa financial distress 
berpengaruh terhadap manajemen laba, sehingga hipotesis pertama dalam penelitian ini diterima.

Hasil penelitian ini menunjukan bahwa koefisien regresi variabel leverage sebesar 4,559 dengan tingkat signifikansi yang diperoleh yakni sebesar 0,121 lebih besar dari $\alpha=0,05$. Hasil penelitian ini menunjukan bahwa financial distress berpengaruh terhadap manajemen laba dengan tingkat signifikansi yang diperoleh yakni sebesar 0,003 lebih besar dari $\alpha=0,05$. Hasil ini menerima hipotesis $H_{1}$ yakni financial distressberpengaruh terhadap manajemen laba. Ini artinya jika perusahaan mengalami kondisi keuslitan keuangan (financial distress), manajer cenderung akan melakukan manipulasi laba dengan menaikan atau menurunkan laba.

Hasil penelitian ini sejalan dengan hasil penelitian yang dilakukan oleh Francisca, dkk. (2014) yang menyatakan kondisi net income negatif cenderung melakkan manajemen laba untuk munurunkan laba (income-dcreasing) dengan cara mengakui semua beban pada saat ini hingga di tahun depan solah-olah ada peningkatan laba (perbaikan kondisi) pada perusahaan tersebut. Sehingga para investor akan melihat jika perusahaan tersebut sudah bangkit atau semakin distress semakin melakukan manajemen laba. Selain itu penelitian yang dilakukan Hapsoro dan Hartono (2016) menyatakan perusahaan yang semakin distress, maka discretionary accruals akan semakin naik. Dengan kata lain, berarti bahwa manajemen pada perusahaan yang mengalami net income maupun modal kerja negatif selama tahun berjalancenderung melakukan manajemen laba untuk meningkatkan laba. 
Kemudian uji hipotesis kedua dengan nilai t hitung sebesar sebesar 2,904 dan nilai signifikansi uji t yakni nilai p-value sebesar 0,011 lebih kecil dari $\alpha=$ 0,05 serta nilai koefisien regresi sebesar 0,403. Ini berarti bahwa GCG berpengaruh dan dapat memoderasi hubungan financial distress terhadap manajemen laba, sehingga hipotesis kedua dalam penelitian ini ditolak.

Hasil pengujian dengan menggunakan Moderated Regression Analysis (MRA) menunjukan bahwa GCG tidak mampu memperlemah pengaruh financial distress terhadap manajemen laba dengan koefisien regresi sebesar 0,304 dan tingkat signifikansi sebesar 0,011 lebih kecil dari $\alpha=0,05$. Hasil ini menolak hipotesis $\mathrm{H}_{2}$ yakni GCG memperlemah pengaruh financial distressterhadap manajemen laba. Ini berarti GCG mampu memoderasi pengaruh financial distress terhadap manajemen laba yang terjadi pada perusahaan LQ45 .

Hal ini membuktikan dewan komisaris independen dan komite audit tidak mampu mencegah adanya praktik manajemen laba di suatu perusahaan. Hal ini disebabkan karena adanya syarat untuk pemenuhan regulasi. Penelitian ini tidak sejalan dengan hasil penelitian yang dilakukan oleh Rice (2016), dan Sri dan Wirawati (2016) yang menyatakan GCG mampu memoderasi terjadinya praktik manajemen laba.

\section{SIMPULAN}

Kesimpulan yang dapat ditarik dari penelitian ini meliputi: 1) Financial distressdengan menggunakan Debt to Equity Ratio (DER) berpengaruh terhadap manajemen laba. Tinggi rendahnya tingkat financial distress suatu perusahaan memengaruhi praktik manajemen laba yang akan dilakukan perusahaan. Ketika 
perusahaan dengan tingkat financial distress yang tinggi akibat besarnya total hutang terhadap total modal akan menghadapi risiko default yang tinggi yaitu perusahaan terancam tidak mampu memenuhi kewajibannya; 2) Dewan komisaris independen dan Komite audittidak mampu memperlemah pengaruh financial distress terhadap manajemen laba. Kemampuan dewan komisaris independen dan komite audit dalam memoderasi pengaruh financial distress terhadap manajemen laba disebabkan karena penerapan dan implementasi tata kelola perusahaan belum berjalan dengan baik dan hanya sebagai pemenuhan regulasi.

Adapun beberapa hal yang dapat disarankan sesuai dengan hasil pembahasan hingga kesimpulan yang disajikan pada penelitian ini meliputi: 1) Peneliti selanjutnya diharapkan menggunakan metode pengukuran variabel good corporate governance (GCG) yang berbeda dan menambah variabelindependen. Penelitian ini hanya meneliti perusahaan yang terdaftar dalam LQ45 di BEI, diharapkan peneliti berikutnya dapat menggunakan seluruh perusahaan yang terdaftar di BEI agar menggeneralisasi hasil penelitian.2) Bagi perusahaan di Indonesia diharapkan untuk meningkatkan penerapan konsep Good Corporate Governance (GCG). Hal ini penting karena bagi pihak eksternal, dengan meningkatkan penerapan konsepGCG dapat memberikan gambaran tentang penerapan GCG di dalam perusahaan dan dapat menjadi nilai tambah dimata investor.3) Investor dalam mengambil keputusan dalam berinvestasi, sebaiknya tidak hanya melihat dari informasi keuangannya saja. Namun juga tetap melihat aspek non keuangan seperti penerapan GCG yang dilakukan oleh perusahaan. 
Karena apabila GCG di suatu perusahaan baik maka pengawasan dan control terhadap kinerja agen akan baik. Hal ini sebagai salah satu cara untuk menekan tindakan oportunistik manajemen.

\section{REFERENSI}

Bistrova, Julia and Natalja Lace. 2012. Quality of Corporate Governance System and Quality of Reported Earnings: Evidence From CEE Companies. Journal of Economics and Managements, Vol. 17, No. 1.

Damodaran, A. 1997. Corporate Finance Theory and Practic, John Wiley dan Sons, Inc,. hal 114: 487 In Hidayat, Muhammad Arif. 2013. Prediksi Financial Distress Perusahaan Manufaktur di Indonesia. Skripsi. Universitas Diponegoro. Semarang.

Dewi Lestari, Sri, Ni Gusti Putu Wirawati. 2016. Good Corporate Governance Sebagai Pemoderasi Pengaruh Asimetri Informasi Pada Manajemen Laba. E-Jurnal Akuntansi Universitas Udayana, 16 (1), hal.156-182.

Dwiyanti, Y. (2016). Kemampuan Rasio Likuiditas, Solvabilitas, Aktifitas Dan Profitabilitas Sebagai Indikator Dalam Memprediksi Financial Distress Pada Perusahaan Go Public Di Bursa Efek Indonesia Tahun 2012-2014.

Ghozali, Imam, 2012. Aplikasi Analisis Multivariet Dengan Program SPSS. Badan Penerbit Universitas Diponegoro

Gunawan, Fransisca Fortunata, Rudiawarni Arni Felizia, Sutanto, A. C. C. (2014). Hubungan antara. Jurnal Ilmiah Mahasiswa Universitas Surabaya, 3(1), 118.

Hair, Joseph F., Black, William C., and Babin, Barry J. 2006. Multivariate Data Analysis Pearson International Sixth Edition.Bandung:Raja Grafindo Persada.

Hapsari, Evanny Indri. 2012. Kekuatan Rasio Keuangan dalam Memprediksi Financial Distress Perusahaan Manufaktur di BEI. Jurnal Dinamika Manajemen Vol. 3 No.2 pp: 101-109.

Hidayat, M. (2014). Pengaruh Good Corporate Governance Dan Ukuran Perusahaan Terhadap Manajemen Laba (Studi Empiris pada Perusahaan LQ45 yang Terdaftar di Bursa Efek Indonesia Periode 2011 - 2014). Ekomoni, 234-248.

Kausalty, P.R, Revanthi, D, and Mohan, T. 2013. "Corporate Governance Model Around The World". Global Research Analysis. 2(3).

Karasek, R., \& Bryant, P. (2012). Signaling theory: Past, present, and future. 
Academy of Strategic Management Journal, 11(1), 91-100.

Komite Nasional Kebijakan Governance (KNKG). 2006. Pedoman Umum Good Corporate Governance Indonesia. Jakarta. Diakses tanggal 10 Juli 2017.

Meeampol, Sasivimol, et al. 2013. The Relationship Between Corporate Governance and Earnings Quality: A Case Study of Listed Companies in the Stock Exchange of Thailand (Set). Active Citizenship by Knowledge Management \& Innovation Learning, International Conference Zadar, Croatia.

Negara, I Putu Agus Atmaja. 2013. Pengaruh Capital Adequacy Rasio dan Penyaluran Kredit Terhadap Profitabilitas dengan Moderasi Non Performing Loan pada bank yang terdaftar di Bursa Efek Indonesia. Skripsi Sarjana Ekonomi Fakultas Ekonomi dan Bisnis Universitas Udayana, Denpasar.

Nindita, K. Moeljadi. Nur K Indrawati, 2014. Prediction on Financial Distress of Mining Companies Listed in BEI Financial Variabel and Non-Financial Variabels. European Journal of Business and Management ,Vol.6, No.34, 2014.

Peranasari, I. A. Agung Istri dan Dharmadiaksa, Ida Bagus. 2014. Perilaku Income Smoothing, Dan Faktor-Faktor Yang Memengaruhinya. Jurnal Akuntansi Universitas Udayana. h; 140-153.

Perwitasari, D. (2014). Struktur Kepemilikan, Karakteristik Perusahaan, dan Manajemen Laba. Jurnal Akuntansi Multiparadigma, 5(3), 432-441.

Putra, i gusti bagus bayu pratama. (2015). Pengaruh Opini Audit Dan Reputasi Kap Pada Auditor Switching Dengan Financial Distress Sebagai Variabel.

Ramantha, I. D. G. P. M. I. W. (2014). Pengaruh Kepemilikan Manajerial dan Kepemilikan Institusional pada Nilai Perusahaan. E-Jurnal Akuntansi Universitas Udayana, 3(9.3), 575-590.

Ratih, Ni Made Dwi Kumala. 2013. Pengaruh Risiko Kredit pada Kinerja Perusahaan dengan Good Corporate Governance Sebagai Pemoderasi Pada Perusahaan Perbankan yang terdaftar di BEI Tahun 2007-2011. Tesis. Program Pascasarjana Universitas Udayana, Denpasar.

Reuer, J. J., Tong, T. W., \& Wu, C. W. (2012). A Signaling theory of acquisition premiums: Evidence from IPO targets. Academy of Management Journal, 55(3), 667-683. https://doi.org/10.5465/amj.2010.0259.

Rice. 2013. Pengaruh Rasio Keuangan dan Corporate Governance Terhadap Praktik Manajeman Laba Pada Perusahaan Kompas100. Jurnal Wira Ekonomi Mikroskil, 3 (2), hal.81-90.

Saraswati, R., Sulistyo, \& Mustikowati, R. I. (2014). Pengaruh Good Corporate Governance dan Financial Distress Terhadap Manajemen Laba (Studi Kasus Pada Perbankan Yang Listing di Bursa Efek Indonesia Periode 2011-2014). 
Journal Riset Mahasiswa, ISSN : 233(6), 1-15.

Sihwahjoeni. (2015). Pengaruh Good Corporate Governance Terhadap Ukuran Perusahaan Dan Dampaknya Pada Manajemen Laba, 3(8), 663-676.

Sugiyono. 2015. Metode Penelitian Pendidikan (Pendekatan Kuantitatif, Kualitatif, dan R\&D). Bandung: CV. Alfabeta.

Sugiyono. 2016. Metode Penelitian Kuantitatif, Kualitatif dan R\&D. Cetakan ke 23. Bandung: CV. Alfabeta

Triwahyuningtias, M. 2012. Analisis pengaruh struktur kepemilikan, ukuran dewan, komisaris independen, likuiditas dan financial distress terhadap terjadinya kondisi financial distress (studi pada perusahaan manufaktur yang terdaftar di bursa efek Indonesia Tahun 2008-2010). Skripsi. Fakultas Ekonomi, Universitas Diponegoro.

Ware, S. J. (2015). Debt, Poverty, and Personal "Financial Distress." American Bankruptcy Law Journal, 89(3), 493-510. https://doi.org/10.1371/journal.pone.0016782 